\title{
Institutionalising Sustainable Development Goals through Decentralised Local-governments in India
}

\section{Pratyusna Patnaik}

Centre for Panchayati Raj, Decentralised Planning \& Social Service Delivery, National Institute of Rural Development E Panchayati Raj (NIRDPR), Rajendranagar, Hyderabad, India

Corresponding author: pratyusna.nird@gov.in

Received: 10-01-2020

Revised: 14-04-2020

Accepted: 25-05-2020

\begin{abstract}
This paper attempts to explore the potentials of decentralised local governments - the Panchayats - in working towards the achievement of global Sustainable Development Goals (SDGs). Having discussed the importance of global development agenda of UN SDGs and their significance for rural development, the paper identifies ten UN SDGs and highlights the actions that the Panchayats can initiate at the grassroots level to realise these goals. The paper concludes that the local governments play a crucial role in achieving the SDGs owing to their strategic position as a link to reduce socio-economic backwardness, promote inclusive development and deepen democracy to the grassroots level.
\end{abstract}

Keywords: Panchayats, Sustainable Development Goals, backwardness

The 2030 Agenda for Sustainable Development is a plan of action for 'people, planet and prosperity', with 17 goals and 169 targets. Considering the importance of rural development in achieving SDGs by 2030 , it is appropriate to highlight that decentralised local government systems of India - Panchayati Raj Institutions - with their emphasis on inclusive development, ensuring social justice and deepening democracy play a significant role in realising the SDGs. The success of these global development agenda lies in its effective institutionalisation at the local and grassroots level, with the active participation of local citizens. It,therefore, becomes essential to highlight the role and the efforts that are to be undertaken by local governments, which will, in turn, help in realisation of larger targets of SDGs.

This paper attempts to explore the potentials of decentralised local governments - the Panchayats - in working towards the achievement of global sustainable development goals. The paper is divided into five sections. Following the introduction, the second section explores the global development agenda and its implication for rural development; and the third section examines the linkages between SDGs and rural development. The fourth section highlights the potential of the panchayats and their roles in achieving globalSDGs. The fifth section summarises the paper and concludes by highlighting the significance of linking the global development agenda with the local development practice.

\section{Global Development Agenda and its implications for Rural Development}

The concept of development, ever since its emergence 
from post-colonial times, has been taken to mean different things at different times, in different places, and by different people in different professions and organisations (Chambers, 2004). Nevertheless, the common theme in most definitions of development entails 'change' in a variety of conditions of human living, through addressing the challenges of poverty, inequality and lack of access to education, health care, employment, housing, water and sanitation, etc. Summarising the meaning of development, Robert Chambers writes "development seems to have had two aspects: it has been normative, and it has involved change. So the underlying meaning of development has been good change" (Chambers, 2004:2). The development literature by late 1970s had made it clear that development cannot be taken to mean only economic growth narrowly, and more important questions of social transformation and social justice, equitable distribution need to be an integral part of the development process. The decade of 1990s witnessed a new era in the conceptualisation of development with the emergence of two new ides in the form of 'sustainable development' and 'human development'.

Conceived in the 1987 World Conference on Environment and Development (WCED), sustainable development rose to prominence from the early 1990s and emerged as one of the most influential thoughts in development discourse. The outcome of WCED - the Brundtland Commission Report - defined sustainable development as 'development that meets the needs of the present generation, without compromising the developmental needs of the future generation' (Adams, 1990). The sustainable development approach brought to the forefront the environmental impacts of development, and called for integrating environmental protection into the agenda of development. While retaining economic growth as the first goal of development, sustainable development, nevertheless argued for a more serious attack on poverty, inequality and environmental degradation, and proposed for an integration of economic (efficiency), social (equity) and environmental (sustainability) into any conceptualisation of development.

With the publication of Human Development Report
(HDR) by UNDP in 1990, development got another lease of life, with the incorporation of notions of quality of life indicators such as literacy (education) and health into development. The Human Development approach brought back the emphasis on social aspects of development and attempted to combine the economistic and human-centric approaches of development. Drawing from multidimensional frameworks such as Rightbased Approach, Sustainable Livelihoods, Happiness Approach, Capability Approach, Empowerment and Freedom (Alkire, 2005; Friedmann, 1992; Robeyns, 2005; Sen, 1999, 2005); Human Development Reports have created a niche for themselves in development discourse. Human Development Approach considered economic growth as a means to achieve development, rather than the goal of development. It believed that improving the lives of people will lead to greater wellbeing for all, rather than assuming that economic growth would result in it. This approach focused on people's basic necessities such as healthcare and education, and called for enlarging opportunities and choices for people. The concept of human development was well accepted by the Indian planned development process, and the Eighth Five-Year Plan formulated in the year 1992 adopted human development as the ultimate goal of all planning processes (Fig. 1).

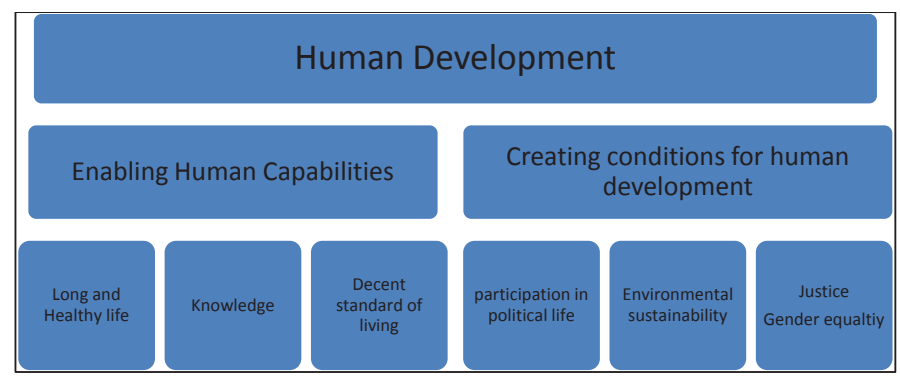

Fig. 1: The Human Development Approach

Source: Sustainable Development Goals and Gram Panchayats, MoPR, GoI

While human development approach produced indices to measure and compare the relative performance of countries, further innovations on the concept of development in the new millennium identified a fixed set of goals with a time frame to achieve human development. The United Nations in September 2000, 
organised the Millennium Summit with attendance of heads of states of 189 countries, and adopted the Millennium Development Goals (MDG). The MDGs dominated the development discourse of 2000s, where the UN and its 189 signatory countries committed themselves to achieve the following eight Goals and 21 targets by 2015 (Fig. 2).

\begin{tabular}{|c|c|}
\hline Goal 1: & - Eradicate Extreme Poverty and Hunger \\
\hline Goal 2: & - Achieve Universal Primary Education \\
\hline Goal 3: & $\begin{array}{l}\text { - Promote Gender Equality and Empower } \\
\text { Women }\end{array}$ \\
\hline Goal 4: & - Reduce Child Mortality Rates \\
\hline Goal 5: & - Improve Maternal Health \\
\hline Goal 6: & - Combat HIV/AIDS, Malaria and other diseases \\
\hline Goal 7: & - Ensure Environmental Sustainability \\
\hline Goal 8: & - Develop a Global Partnership for Development \\
\hline
\end{tabular}

Fig. 2: Millennium Development Goals (MDGs)

The MDGs, which set for a 15 years target at the beginning of the millennium, were extended in the recent UN Sustainable Development Summit of September 2015. On $25^{\text {th }}$ September 2015, 193 world leaders adopted a global development vision called Transforming our World: The 2030 Agenda for Sustainable Development. The 2030 Agenda is "a plan of action for people, planet and prosperity". The 2030 Agenda contains 17 new Sustainable Development Goals (SDGs) and 169 targets to stimulate global action over the next 15 years on issues critical to humanity and the planet. It has become applicable from January 2016. The deadline for the SDGs is 2030. The 2030 new Development Agenda is committed to 17 global goals with an aim to: (a) end extreme poverty, (b) fight inequality and injustice, and (c) fix climate change by 2030 .

\section{The 17 Sustainable Development Goals}

* Goal 1: End poverty in all its forms everywhere

* Goal 2: End hunger, achieve food security and improved nutrition and promote sustainable agriculture

* Goal 3: Ensure healthy lives and promote wellbeing for all at all ages
* Goal 4: Ensure inclusive and equitable quality education and promote lifelong learning opportunities for all

* Goal 5: Achieve gender equality and empower all women and girls

* Goal 6: Ensure availability and sustainable management of water and sanitation for all

- Goal 7: Ensure access to affordable, reliable, sustainable and modern energy for all

* Goal 8: Promote sustained, inclusive and sustainable economic growth, full and productive employment and decent work for all

- Goal 9: Build resilient infrastructure, promote inclusive and sustainable industrialisation and foster innovation

* Goal 10: Reduce inequality within and among countries

* Goal 11: Make cities and human settlements inclusive, safe, resilient and sustainable

* Goal 12: Ensure sustainable consumption and production patterns

- Goal 13: Take urgent action to combat climate change and its impacts

* Goal 14: Conserve and sustainably use the oceans, seas and marine resources for sustainable development

- Goal 15: Protect, restore and promote sustainable use of terrestrial ecosystems, sustainably manage forests, combat desertification, and halt and reverse land degradation and halt biodiversity loss

- Goal 16: Promote peaceful and inclusive societies for sustainable development, provide access to justice for all and build effective, accountable and inclusive institutions at all levels

* Goal 17: Strengthen the means of implementation and revitalise the global partnership for sustainable development. 
A pictorial representation of the SDGs

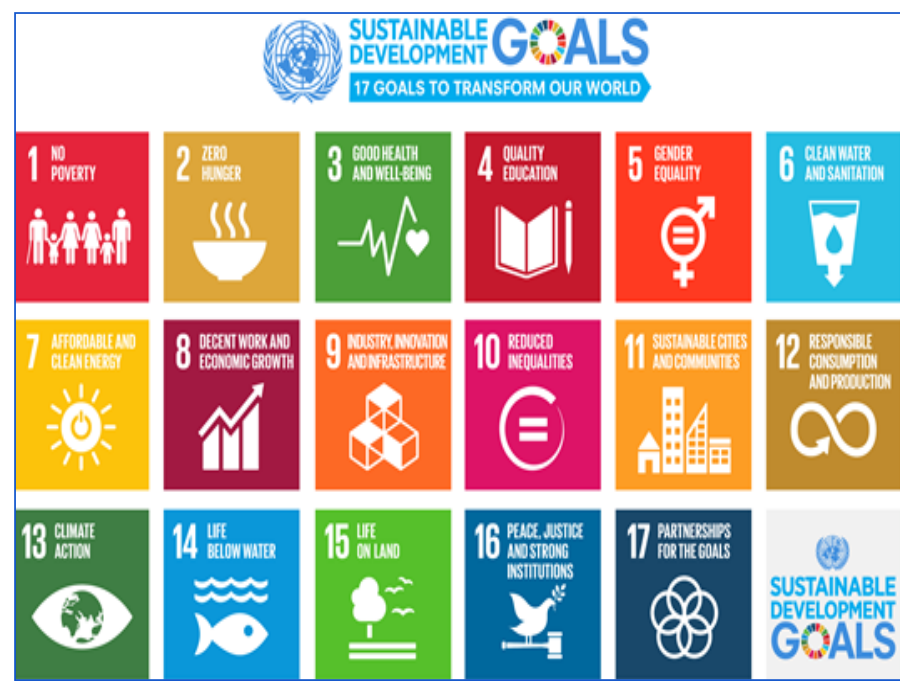

Source: $h$ ttps://sdgs.un.org/goals

\section{Rural Development and Sustainable Development Goals}

In September 2015, the United Nations, along with its 193 member countries, including India, adopted a global development vision called Sustainable Development Goals, 2030 (SDGs 2030). The SDGs cover a broad range of interconnected issues, from economic growth, social and environmental issues to global public goods like ending poverty and hunger, improving health and education, making cities more sustainable and combating climate change. The SDGs are integrated, indivisible and balance the three dimensions of sustainable development: the economic, social and environmental development. The 5Ps of SDGs are people, planet, peace, partnership and prosperity. All the member countries have framed their agendas and policies to end poverty, protect the planet, enjoy the peace and ensure prosperity for all by 2030.

In India, with its emphasis on poverty eradication, food security, health, education, gender equality, access to water and sanitation, employment, SDGs necessarily remains connected to fundamental goals of rural development. Rural development is expected to play a significant role in achieving these SDGs in a developing country like India, owing to its predominantly rural population. As per the Census of India 2011, slightly more than two-thirds of the total population of the country live in rural areas. With the majority of the poor staying in rural areas with limited access to education, food security, health care systems, water and sanitation, achieving SDGs by 2030 largely depends upon rural development initiatives.

Further, most of the challenges of development that SDGs aim to address are predominantly problems of rural India. It is, therefore, unthinkable to achieve the SDGs without proper emphasis on achieving effective rural development outcomes. A second reason for the importance of rural development in achieving SDGs is the role of the agricultural sector in employment (UNCTAD, 2015). Despite a slight reduction, the proportion of people engaged in agriculture remains at $60-70$ per cent. Therefore, addressing the SDGs of hunger and employment necessitates increased attention being paid to sustainable agricultural and rural development practices in the country.

The targets of SDGs are directly or indirectly related to the responsibilities of local and regional governments. Therefore, the democratic local governments called the Panchayati Raj Institutions (PRIs) as the grassroots units of local governments will have crucial responsibilities in achieving the SDGs. Considering the importance of rural development in achieving SDGs by 2030, it is appropriate to highlight that Panchayati Raj Institutions (PRIs) with their emphasis on inclusive development, ensuring social justice and deepening democracy will have to play a significant role in realising the sustainable development goals. The following section discusses the SDGs that are directly related to Gram Panchayats and explore what actions the Panchayats can take to achieve these goals.

\section{Sustainable Development Goals (SDGs) and Decentralised Local Governments}

The 2030 Agenda for Sustainable Development and the priorities of inclusive rural development are in tandem with each other, and Panchayats play a significant role for achieving both. It is, therefore, becomes appropriate to discuss the role and efforts that are being undertaken by Panchayats to realise the broader Sustainable Development Goals. Following the $73^{\text {rd }}$ Constitutional 
Amendment to Indian Constitution, 1993 Panchayats are expected to play critical roles in the thematic areas enlisted as 29 functions in the Eleventh Schedule of the Constitution. Further, many of the SDGs targets are within the purview of the 29 subjects devolved to the Panchayats under the Eleventh Schedule. Besides, the Gram Panchayat Development Plan (GPDP) initiated after the recommendation of the $14^{\text {th }}$ Finance Commission (FFC) which came into force from 2015 makes necessary institutional arrangements for planning inclusive development of Panchayats to achieve the SDGs. Further, the Fourteenth Finance Commission (FFC) has granted a total of ₹ 2,00,292 Crores to the Panchayats over the year 2015 to 2020 in order to meet their stated mandates of promoting the overall development of rural societies.

The importance of PRIs in achieving SDGs becomes explicit from the fact that most of the SDGs targets are within the purview of functions listed in the Eleventh Schedule of the Constitution. Besides, several centrally sponsored schemes implemented through the Panchayats are also at the core of the SDGs, and thus Panchayats play a crucial role in achieving these targets of SDGs. The first and second goals of SDG, i.e. 'no poverty' and 'no hunger' require a wider definition of poverty involving equal rights to economic resources as well as access to essential services such as safe drinking water, sanitation, education, housing etc. (Mohanty, 2017). In the context of rural development, most of these developmental functions are fulfilled by Panchayats, and hence it becomes difficult to undermine the significance of PRIs in achieving SDGs. In order to fulfil the $2^{\text {nd }}$ goal of SDG (no hunger), it is imperative to increase the productivity of agriculture and income of small and marginal farmers, and to ensure access to land and other economic resources to these groups. On the other hand, Panchayats also play a crucial role in improvement of agriculture, management of minor irrigation, minor forest produces, etc. Thus it becomes evident that functions of Panchayats are always in tandem with various targets of SDGs.

One of the initial step to realise SDGs through Panchayats is to integrate the targets of SDGs in the planning process of Panchayats through the Gram Panchayat
Development Plan (GPDP). The local development plans of Panchayats are expected to be synchronised with the targets of SDGs. Out of the 17 SDGs, the Ministry of Panchayati Raj (MoPR), GoI identifies ten goals where the Panchayats play a crucial role, and envisages the following roles and initiatives by Panchayats in order to timely achievement of SDGs. The details are provided in the following table (Table 1):

Table 1: Initiatives to be taken up by Panchayats to achieve SDGs

\begin{tabular}{|c|c|}
\hline $\begin{array}{l}\text { Sustainable Development } \\
\text { Goals (SDGs) }\end{array}$ & $\begin{array}{l}\text { Initiatives to be taken up by } \\
\text { Panchayats }\end{array}$ \\
\hline $\begin{array}{l}\text { End Poverty in all its forms } \\
\text { everywhere }\end{array}$ & $\begin{array}{l}\text { Panchayats can identify poor, } \\
\text { destitute and vulnerable and } \\
\text { can facilitate access to social } \\
\text { protection, housing, water, } \\
\text { sanitation and electricity. } \\
\text { Panchayats can ensure income } \\
\text { generation through skill } \\
\text { training, entrepreneurship } \\
\text { development, employment } \\
\text { generation through } \\
\text { proper implementation of } \\
\text { MGNREGA. }\end{array}$ \\
\hline $\begin{array}{l}\text { End hunger, achieve food } \\
\text { security and improve } \\
\text { nutrition }\end{array}$ & $\begin{array}{l}>\text { Panchayats can enrol families } \\
\text { under PDS, children, pregnant } \\
\text { women and adolescent girls } \\
\text { under ICDS. } \\
>\text { Panchayats can promote } \\
\text { breastfeeding and locally } \\
\text { available nutritious food. }\end{array}$ \\
\hline $\begin{array}{l}\text { Ensure healthy lives and } \\
\text { promote well-being for all } \\
\text { at all ages }\end{array}$ & $\begin{array}{l}\text { Panchayats can maintain and } \\
\text { monitor the quality of health } \\
\text { care services and overall } \\
\text { cleanliness to combat diseases. } \\
\text { Panchayats can ensure the } \\
\text { effective functioning of } \\
\text { village health, sanitation and } \\
\text { nutrition committees, and } \\
\text { address local health issues } \\
\text { through GPDP. } \\
\text { Panchayats can promote the } \\
\text { enrolment of vulnerable in } \\
\text { health insurance schemes. }\end{array}$ \\
\hline
\end{tabular}




\begin{tabular}{|c|c|}
\hline $\begin{array}{l}\text { Ensure inclusive and } \\
\text { equitable quality education } \\
\text { and promote lifelong } \\
\text { learning opportunities for } \\
\text { all }\end{array}$ & $\begin{array}{l}\text { Panchayat can facilitate } \\
\text { transport and hostels for } \\
\text { children in isolated areas, } \\
\text { and provide scholarships, } \\
\text { uniforms and mid-day meals } \\
\text { in schools. } \\
\text { Panchayats can facilitate to } \\
\text { build girls' toilets in schools } \\
\text { to ensure the retention of girls. } \\
\text { Panchayats can promote } \\
\text { awareness on the rights of } \\
\text { children and the Right to } \\
\text { Education Act, and build } \\
\text { environment for } 100 \text { per cent } \\
\text { enrolment and retention of } \\
\text { students in schools. } \\
\text { Panchayats can strengthen } \\
\text { preschool, Anganwadi welfare } \\
\text { committees. }\end{array}$ \\
\hline $\begin{array}{l}\text { Achieve gender equality } \\
\text { and empower all women } \\
\text { and girls }\end{array}$ & $\begin{array}{l}\text { Panchayats can promote } \\
\text { awareness against gender } \\
\text { discrimination and ensure } \\
\text { proper implementation of Beti } \\
\text { Bachao Beti Padhao Yojna. } \\
\text { Panchayat can facilitate } \\
\text { women's participation in } \\
\text { economic activities under } \\
\text { SHGs. } \\
\text { Panchayat can ensure that } \\
\text { gender discriminatory } \\
\text { practices do not take place. }\end{array}$ \\
\hline $\begin{array}{l}\text { Ensure availability and } \\
\text { sustainable management of } \\
\text { water and sanitation for all }\end{array}$ & $\begin{array}{l}\text { Panchayats can ensure } \\
\text { identification of households } \\
\text { without toilets and help in the } \\
\text { construction of toilets in those } \\
\text { households and institutions. } \\
>\text { Panchayats can ensure solid } \\
\text { and liquid waste management } \\
\text { by way of including water and } \\
\text { sanitation priorities in GPDP. } \\
\text { Panchayats can facilitate } \\
\text { appropriate irrigation } \\
\text { methods, the participation of } \\
\text { local communities in water } \\
\text { and sanitation management } \\
\text { and regulate excessive water } \\
\text { extraction. }\end{array}$ \\
\hline
\end{tabular}

\begin{tabular}{|c|c|}
\hline $\begin{array}{l}\text { Ensure access to affordable, } \\
\text { reliable, sustainable and } \\
\text { modern energy for all }\end{array}$ & $\begin{array}{l}\text { Panchayats can facilitate } \\
\text { electricity connection to } \\
\text { households, public buildings, } \\
\text { commercial establishments } \\
\text { and for irrigation facilities. } \\
\text { Panchayats can popularise } \\
\text { construction of biogas } \\
\text { systems, energy-efficient } \\
\text { building designs. } \\
>\text { Panchayats can facilitate solar } \\
\text { energy augmentation and } \\
\text { installation of energy-efficient } \\
\text { challahs. }\end{array}$ \\
\hline $\begin{array}{l}\text { Promote sustained, } \\
\text { inclusive and sustainable } \\
\text { economic growth, full and } \\
\text { productive employment } \\
\text { and decent work for all }\end{array}$ & $\begin{array}{l}\text { Panchayats can map micro, } \\
\text { small and medium enterprises } \\
\text { and other employment } \\
\text { opportunities. } \\
\text { Panchayats can facilitate job } \\
\text { creation through convergence } \\
\text { of on-going schemes and } \\
\text { effective implementation of } \\
\text { MGNREGS. } \\
\text { Panchayat can create } \\
\text { awareness on equal wages } \\
\text { for men and women for equal } \\
\text { work. }\end{array}$ \\
\hline $\begin{array}{l}\text { Take urgent action to } \\
\text { combat climate change and } \\
\text { its impact. }\end{array}$ & $\begin{array}{l}\text { Panchayats can integrate } \\
\text { sectoral climate change } \\
\text { considerations into local } \\
\text { planning. } \\
\text { Panchayats can build } \\
\text { strategies to mitigate climate } \\
\text { change risks and plan to } \\
\text { reduce dependence on } \\
\text { climate-sensitive sectors. }\end{array}$ \\
\hline $\begin{array}{l}\text { Protect, restore and } \\
\text { promote sustainable use } \\
\text { of terrestrial ecosystems, } \\
\text { sustainably manage forests, } \\
\text { combat desertification } \\
\text { and halt and reverse land } \\
\text { degradation and halt } \\
\text { biodiversity loss }\end{array}$ & $\begin{array}{l}\text { Panchayats can promote } \\
\text { conservation of micro } \\
\text { watersheds, sacred groves, } \\
\text { wetlands. } \\
\text { Panchayats can initiate } \\
\text { afforestation drives through } \\
\text { programmes like MGNREGS. } \\
\text { Panchayats can facilitate the } \\
\text { renovation of existing ponds, } \\
\text { construction of check-dams } \\
\text { and contour bunds. }\end{array}$ \\
\hline
\end{tabular}




\section{CONCLUSION}

Sustainable Development Goals are universal goals with local implications and possibilities of intervention at the local government level. Panchayats have a crucial role to play in achieving the SDGs. It is essential to mention that the Constitution of India envisages ensuring economic development and social justice as the two prominent mandates of Panchayati Raj systems. Thus, the local governments play a crucial role in achieving the SDGs owing to their strategic position as a link to reduce socio-economic backwardness, promote inclusive development and deepen democracy to the grassroots level. The decentralised local governments can ensure that the global vision is translated to local policies by bringing locally relevant initiatives into global policy debates and offer examples of best practices across the Panchayats in India.

\section{REFERENCES}

Adams, W.M. 1990. Green Development: Environment and Sustainability in the Third World. New York: Routledge.

Alkire, S. 2005. Why Capability Approach? Journal of Human Development, 6(1): 115-133.

Chambers, R. 2004. Ideas for Development: Reflecting Forward (No. 238). Sussex, England.

Friedmann, J. 1992. Empowerment: The Politics of Alternative Development. Oxford: Blackwell Publishers.

Robeyns, I. 2005. The Capability Approach: a theoretical survey. Journal of Human Development, 6(1): 93-117.

Sen, A. 1999. Development as Freedom. Oxford: Oxford University Press.

Sen, A. 2005. Human Rights and Capabilities. Journal of Human Development and Capabilities, 6(2): 151-166. 